\section{THE SIPRI TOP 100 ARMS-PRODUCING AND MILITARY SERVICES COMPANIES, 2013}

\section{AUDE FLEURANT AND SAM PERLO-FREEMAN}

The sales of arms and military services by the SIPRI Top 100-the world's 100 largest arms-producing and military services companies (excluding China, see box 1), ranked by their arms sales-totalled $\$ 402$ billion in 2013. This is a decrease of 2.0 per cent in real terms compared to Top 100 revenues in 2012, continuing the decline that started in 2011, but at a slower rate. Despite three consecutive years of decreasing sales for the Top 100, total revenues remain 45.5 per cent higher in real terms than for the Top 100 in 2002 (see figure 1).

\section{DEVELOPMENTS IN THE TOP 100}

This edition of the SIPRI Top 100 arms-producing and military services companies fact sheet introduces a new category, 'emerging producers', to classify companies in Brazil, India, Republic of Korea (South Korea),

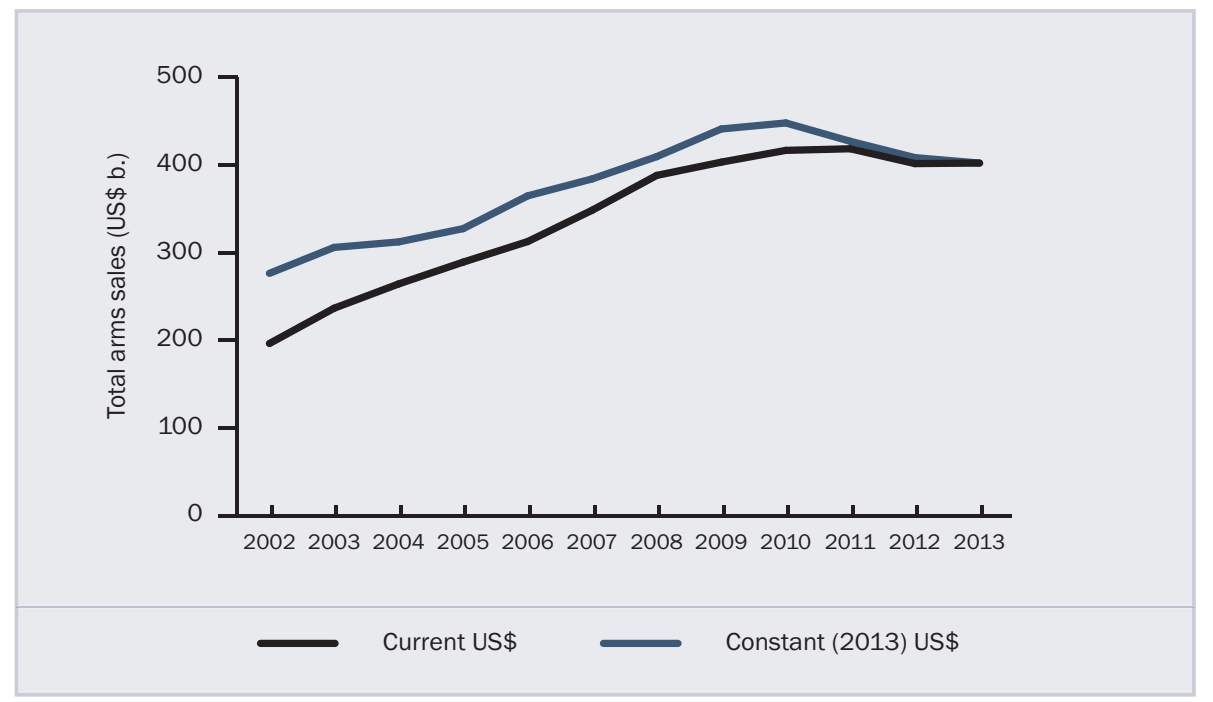

Figure 1. Total arms sales of companies in the SIPRI Top 100, 2002-13

Note: The data in this graph refers to the companies in the SIPRI Top 100 in each year, which means that they refer to a different set of companies each year, as ranked from a consistent set of data.

'Arms sales' refers to sales of military equipment and services to armed forces and ministries of defence worldwide. For a full definition see <http://www.sipri.org/ research/armaments/production/Top100> or SIPRI Yearbook 2014.

\section{KEY FACTS}

- The arms sales of the SIPRI Top 100 arms-producing and military services companies in 2013 (outside China) totalled $\$ 402$ billion. With a 2 per cent decrease, this is the third consecutive annual fall.

- The global fall in arms sales that started in 2011 is continuing, but at a slower pace. So far, fears of a deep decline in arms sales for US and West European companies have not materialized.

- A little over two-thirds of the companies in the Top 100 for 2013 are headquartered in North America or Western Europe. They accounted for 84.2 per cent of the total arms sales.

- Arms sales by Top 100 companies from the rest of the world rose by 9.2 per cent in real terms; the share of the total Top 100 held by these companies is now at its highest level ever.

- The total estimated arms sales of the 10 Russian companies in the Top 100 is $\$ 31$ billion for 2013. Nine Russian arms companies were ranked in the 2012 Top 100. Their arms sales grew by 20 per cent between 2012 and 2013.

- US companies experiencing the most important drops in sales for 2013 were those whose business was linked to overseas operations.

- Sales of companies headquartered in Western Europe remained mostly stable at the regional level with a very slight decrease of 0.9 per cent. 


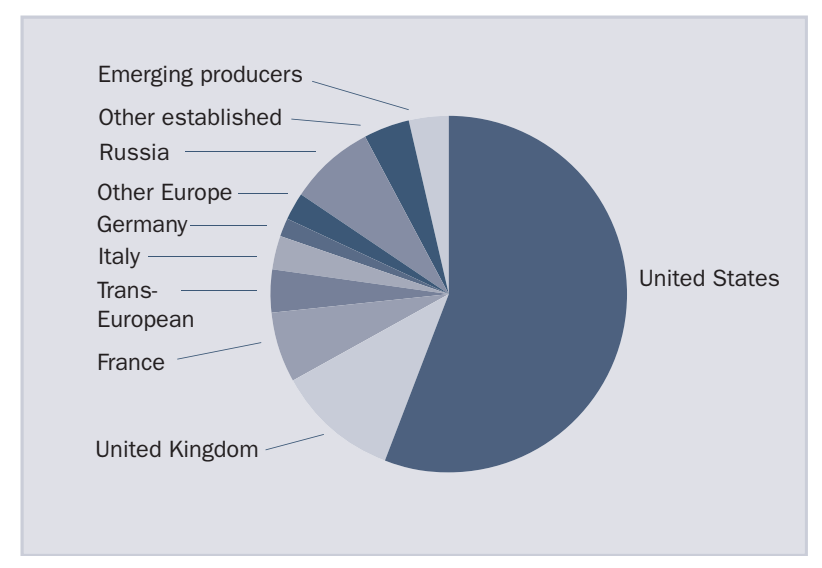

Figure 2. Share of arms sales of companies in the SIPRI Top 100 for 2013, by country

Notes: The Top 100 classifies companies according to the country in which they are headquartered, so sales by an overseas subsidiary will be counted towards the total for the parent company's country. The Top 100 does not include the entire arms industry in each country covered, only the largest companies.

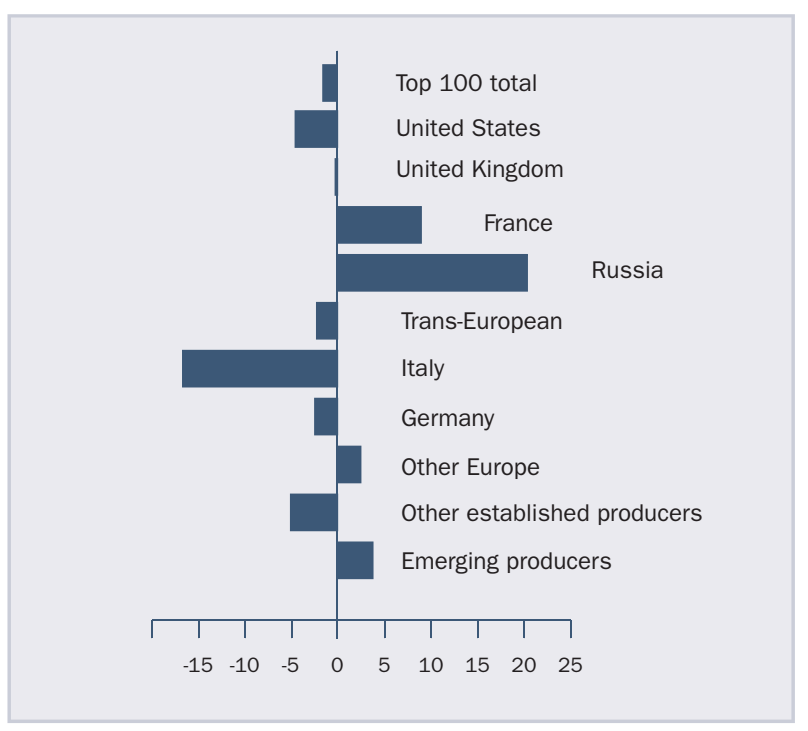

Figure 3. Percentage change in arms sales of companies in the SIPRI Top 100, by country, 2012-13 Note: The change refers to the companies in the Top 100 for 2013. The figures are based on arms sales in constant (2013) US\$.
Singapore and Turkey. The new category better tracks the progression of these countries in the global arms industry. In 2013, emerging arms-producing and military services companies accounted for 3.6 per cent of the total arms sales of the Top 100 (see figure 2).

Companies headquartered in North America and Western Europe continue to dominate the global arms industry and comprised 69 of the Top 100 companies for 2013 (see figure 3). They accounted for 84.2 per cent of the total arms sales of the Top 100-a slight drop from 85.3 per cent in 2012. The total arms sales of the 39 ranked North American companies ( 38 from the United States and 1 from Canada) fell by 4.5 per cent in real terms in 2013. The decrease for West European companies (30 in the Top 100) was a modest 2 per cent in real terms.

Other established arms producers in the Top 100-such as Australia, Israel, Japan, Ukraine and Russia (20 companies)-represented 12.1 per cent of the total arms sales of the Top 100 in 2013. This compares with 11.4 per cent for the same category in 2012. Poland's only ranking company in 2012, Polish Defense Holdings, exited the Top 100 in 2013.

Although the predominance of US-and, to a lesser extent, West European-arms companies remains a central feature of global arms production and will likely continue as such for the foreseeable future, regional trends suggest a persistent relative decline of major US and West European arms producers following the 2008 global financial crisis and the end of major military operations in Afghanistan and Iraq.

Given the methodological difficulties posed by the lack of transparency about China's arms sales, SIPRI data does not cover China's arms-producing companies (see box 1). Thus, trends in this fact sheet exclude Chinese arms producers.

\section{THE 10 LARGEST COMPANIES}

All of the companies in the Top 10 were headquartered in the USA and Western Europe. Their share of the total arms sales of the Top 100 in 2013 was 50.3 per cent, a decline from 51.6 per cent in 2012. Except for the move of the French company Thales into 10th position, the 10 largest companies in the Top 100 remain largely the same in 2013 as it did in 2012.

\section{NATIONAL DEVELOPMENTS}

\section{Russia}

Ten Russian arms-producing and military services companies ranked in the SIPRI Top 100, compared with nine companies in 2012. SIPRI estimates that grow th in revenues for the nine companies listed in the 2012 Top 100 is 20 per cent. This is a smaller expansion than the one observed for the same group 
Table 1. The SIPRI Top 100 arms-producing and military services companies in the world excluding China, $2013^{a}$

Figures for arms sales, total sales and total profit are in millions of US\$. Dots (..) indicate that data is not available.

\begin{tabular}{|c|c|c|c|c|c|c|c|c|c|}
\hline \multicolumn{2}{|c|}{$\operatorname{Rank}^{b}$} & \multirow[b]{2}{*}{ Company $^{c}$} & \multirow[b]{2}{*}{ Country } & \multicolumn{2}{|c|}{$\begin{array}{l}\text { Arms sales } \\
\text { (US\$ m.) }\end{array}$} & \multirow{2}{*}{$\begin{array}{l}\text { Total } \\
\text { sales, } 2013 \\
\text { (US\$ m.) }\end{array}$} & \multirow{2}{*}{$\begin{array}{l}\text { Arms sales } \\
\text { as a \% of } \\
\text { total sales, } \\
2013\end{array}$} & \multirow{2}{*}{$\begin{array}{l}\text { Total } \\
\text { profit, } \\
2013 \\
\text { (US\$ m.) }\end{array}$} & \multirow{2}{*}{$\begin{array}{l}\text { Total } \\
\text { employment, } \\
2013\end{array}$} \\
\hline 2013 & 2012 & & & 2013 & 2012 & & & & \\
\hline 1 & 1 & Lockheed Martin & USA & 35490 & 36000 & 45500 & 78 & 2981 & 115000 \\
\hline 2 & 2 & Boeing & USA & 30700 & 30600 & 86623 & 35 & 4585 & 168400 \\
\hline 3 & 3 & BAE Systems & $\mathrm{UK}$ & 26820 & 26770 & 28406 & 94 & 275 & 84600 \\
\hline 4 & 4 & Raytheon & USA & 21950 & 22500 & 23706 & 93 & 2013 & 63000 \\
\hline 5 & 6 & Northrop Grumman & USA & 20200 & 19400 & 24661 & 82 & 1952 & 65300 \\
\hline 6 & 5 & General Dynamics & USA & 18660 & 20940 & 31218 & 60 & 2357 & 96000 \\
\hline 7 & 7 & $\mathrm{EADS}^{d}$ & $\begin{array}{l}\text { Trans- } \\
\text { European }\end{array}$ & 15740 & 15400 & 78693 & 20 & 1959 & 144060 \\
\hline 8 & 9 & United Technologies (UTC) & USA & 11900 & 12120 & 62626 & 19 & 5721 & 212000 \\
\hline 9 & 8 & Finmeccanica & Italy & 10560 & 12530 & 21292 & 50 & 98 & 63840 \\
\hline 10 & 11 & Thales & France & 10370 & 8880 & 18850 & 55 & 761 & 65190 \\
\hline 11 & 10 & L-3 Communications & USA & 10340 & 10840 & 12629 & 82 & 778 & 48000 \\
\hline $\mathrm{S}$ & $S$ & $\begin{array}{l}\text { BAE Systems Inc. (BAE } \\
\text { Systems UK) }\end{array}$ & USA & 10300 & 10370 & 11363 & 91 & .. & .. \\
\hline 12 & 14 & Almaz-Antey & Russia & 8030 & 5810 & 8547 & 94 & 399 & .. \\
\hline $\mathrm{S}$ & S & EADS Cassidian (EADS) & $\begin{array}{l}\text { Trans- } \\
\text { European }\end{array}$ & 6750 & 6420 & 7936 & 85 & 566 & 28800 \\
\hline 13 & 13 & $\begin{array}{l}\text { Huntington Ingalls } \\
\text { Industries }\end{array}$ & USA & 6550 & 6440 & 6820 & 96 & 261 & 38000 \\
\hline 14 & 17 & Rolls-Royce & UK & 5550 & 4990 & 24239 & 23 & 2155 & 55200 \\
\hline 15 & 18 & $\begin{array}{l}\text { United Aircraft } \\
\text { Corporation }^{i}\end{array}$ & Russia & 5530 & 4440 & 6913 & 80 & 1395 & .. \\
\hline 16 & 15 & Safran & France & 5420 & 5300 & 19515 & 28 & 1584 & 66230 \\
\hline 17 & 19 & $\begin{array}{l}\text { United Shipbuilding } \\
\text { Corporation }^{i}\end{array}$ & Russia & 5120 & 4150 & 6377 & 80 & 94 & .. \\
\hline 18 & 16 & Honeywell & USA & 4870 & 5110 & 39055 & 12 & 3924 & 131000 \\
\hline $\mathrm{S}$ & $S$ & Pratt \& Whitney (UTC) & USA & 4800 & 4200 & 14501 & 33 & 1876 & 31700 \\
\hline 19 & 24 & DCNS & France & 4460 & 3580 & 4460 & 100 & 138 & 13650 \\
\hline 20 & 25 & Textron & USA & 4380 & 3550 & 12104 & 36 & 498 & 32000 \\
\hline 21 & 29 & Booz Allen Hamilton & USA & 4100 & 3200 & 5479 & 75 & 232 & 22700 \\
\hline 22 & 12 & Leidos $^{j}$ & USA & 3930 & 7820 & 5772 & 68 & 164 & 22000 \\
\hline 23 & 20 & General Electric & USA & 3850 & 4100 & 146045 & 3 & 13057 & 307000 \\
\hline $\mathrm{S}$ & $S$ & Eurocopter Group (EADS) & France & 3760 & 3700 & 8363 & 45 & 526 & 22400 \\
\hline $\mathrm{S}$ & $S$ & $\begin{array}{l}\text { MBDA (BAE Systems } \\
\text { UK/EADS W. Eur. / } \\
\text { Finmeccanica Italy) }\end{array}$ & $\begin{array}{l}\text { Trans- } \\
\text { European }\end{array}$ & 3720 & 3860 & 3718 & 100 & .. & 10000 \\
\hline $\mathrm{S}$ & $S$ & Sikorsky (UTC) & USA & 3630 & 4510 & 6253 & 58 & 594 & 16520 \\
\hline 24 & 22 & ITT Exelis & USA & 3560 & 3800 & 4816 & 74 & 281 & 17200 \\
\hline 25 & 26 & Vertolety Rossii $^{e}$ & Russia & 3500 & 3520 & 4343 & 80 & 298 & 41200 \\
\hline 26 & 30 & $\begin{array}{l}\text { Babcock International } \\
\text { Group }\end{array}$ & UK & 3270 & 3180 & 5543 & 59 & 407 & 10260 \\
\hline 27 & 32 & $\begin{array}{l}\text { Mitsubishi Heavy } \\
\text { Industries } f\end{array}$ & Japan & 3240 & 3010 & 34318 & 9 & 1643 & 80580 \\
\hline 28 & 27 & CACI International & USA & 3200 & 3300 & 3565 & 90 & 136 & 15300 \\
\hline $\mathrm{S}$ & $\mathrm{S}$ & $\begin{array}{l}\text { AgustaWestland } \\
\text { (Finmeccanica) }\end{array}$ & Italy & 3180 & 2940 & 5413 & 59 & 345 & 13230 \\
\hline 29 & - & Science Applications ${ }^{k}$ & USA & 3170 & . & 4121 & 77 & 113 & 13000 \\
\hline 30 & 21 & Oshkosh Truck & USA & 3050 & 3950 & 7665 & 40 & 316 & 11900 \\
\hline
\end{tabular}




\begin{tabular}{|c|c|c|c|c|c|c|c|c|c|}
\hline \multicolumn{2}{|c|}{$\operatorname{Rank}^{b}$} & \multirow[b]{2}{*}{ Company $^{c}$} & \multirow[b]{2}{*}{ Country } & \multicolumn{2}{|c|}{$\begin{array}{l}\text { Arms sales } \\
\text { (US\$ m.) }\end{array}$} & \multirow{2}{*}{$\begin{array}{l}\text { Total } \\
\text { sales, } 2013 \\
\text { (US\$ m.) }\end{array}$} & \multirow{2}{*}{$\begin{array}{l}\text { Arms sales } \\
\text { as a \% of } \\
\text { total sales, } \\
2013\end{array}$} & \multirow{2}{*}{$\begin{array}{l}\text { Total } \\
\text { profit, } \\
2013 \\
\text { (US\$ m.) }\end{array}$} & \multirow{2}{*}{$\begin{array}{l}\text { Total } \\
\text { employment } \\
2013\end{array}$} \\
\hline 2013 & 2012 & & & 2013 & 2012 & & & & \\
\hline 31 & 34 & Saab & Sweden & 2950 & 2900 & 3645 & 81 & 114 & 14140 \\
\hline 32 & 33 & Rheinmetall & Germany & 2860 & 3000 & 6126 & 47 & 283 & 21080 \\
\hline 33 & 28 & Harris $^{i}$ & USA & 2850 & 3220 & 5012 & 57 & 534 & 14000 \\
\hline 34 & 39 & Bechtel $^{h}$ & USA & 2800 & 2500 & 39400 & 7 & .. & .. \\
\hline 35 & 36 & Elbit Systems & Israel & 2780 & 2740 & 2922 & 95 & 824 & 11670 \\
\hline 36 & 42 & United Engine Corporation ${ }^{i}$ & Russia & 2720 & 2460 & 4995 & 54 & 9 & 83400 \\
\hline 37 & 40 & Hewlett-Packard $g$ & USA & 2700 & 2500 & 112298 & 2 & 5113 & 315700 \\
\hline 38 & 38 & Israel Aerospace Industries & Israel & 2660 & 2540 & 3642 & 73 & 83 & .. \\
\hline 39 & 47 & Serco $^{i}$ & $\mathrm{UK}$ & 2560 & 2200 & 8037 & 32 & 149 & 120540 \\
\hline $\mathrm{S}$ & S & EADS Astrium (EADS) & France & 2530 & 2540 & 7681 & 33 & 456 & 17000 \\
\hline 40 & 23 & Computer Sciences Corp. & USA & 2400 & 3690 & 12998 & 18 & 674 & 79000 \\
\hline 41 & 37 & Rockwell Collins & USA & 2400 & 2590 & 4610 & 52 & 632 & 18300 \\
\hline 42 & 43 & Hindustan Aeronautics & India & 2390 & 2430 & 2582 & 93 & 467 & .. \\
\hline 43 & 35 & URS Corporation & USA & 2310 & 2850 & 10991 & 21 & 247 & 50000 \\
\hline 44 & 46 & General Atomics ${ }^{h}$ & USA & 2280 & 2200 & .. & .. & .. & .. \\
\hline 45 & 48 & CEA & France & 2270 & 2190 & 5732 & 40 & 57 & 15870 \\
\hline 46 & 74 & $\begin{array}{l}\text { Tactical Missiles } \\
\text { Corporation }\end{array}$ & Russia & 2230 & 990 & 2421 & 92 & 138 & 39890 \\
\hline 47 & 41 & ManTech International & USA & 2210 & 2470 & 2310 & 96 & -615 & 7800 \\
\hline S & $S$ & Sukhoi (UAC) & Russia & 2180 & 2310 & 2813 & 78 & 379 & .. \\
\hline 48 & 31 & Dyncorp & USA & 2120 & 3040 & 3287 & 65 & -254 & 20000 \\
\hline 49 & 51 & ST Engineering & Singapore & 2020 & 1890 & 5302 & 38 & 464 & 22840 \\
\hline 50 & 45 & Fluor $^{h}$ & USA & 1970 & 2260 & 27352 & 7 & 668 & 38130 \\
\hline 51 & 54 & Rafael & Israel & 1960 & 1700 & 2001 & 98 & 99 & 7000 \\
\hline $\mathrm{S}$ & $S$ & $\begin{array}{l}\text { Selex ES SpA } \\
\text { (Finmeccanica) }\end{array}$ & Italy & 1930 & 880 & 2641 & 73 & -426 & 10600 \\
\hline 52 & 57 & Dassault Aviation Groupe & France & 1860 & 1470 & 6100 & 31 & 647 & 11600 \\
\hline 53 & 60 & KRET & Russia & 1850 & 1380 & 2427 & 76 & 207 & 48550 \\
\hline $\mathrm{S}$ & S & $\begin{array}{l}\text { Dassault Aviation (Dassault } \\
\text { Aviation Groupe) }\end{array}$ & France & 1840 & 1410 & 5267 & 35 & 478 & 8080 \\
\hline 54 & 49 & Indian Ordnance Factories & India & 1820 & 2130 & 1918 & 95 & .. & 93520 \\
\hline 55 & 52 & Cobham & UK & 1820 & 1880 & 2797 & 65 & 361 & 10090 \\
\hline 56 & 44 & Alliant Techsystems & USA & 1820 & 2330 & 4775 & 38 & 341 & 16000 \\
\hline S & $S$ & $\begin{array}{l}\text { Alenia Aermacchi } \\
\text { (Finmeccanica) }\end{array}$ & Italy & 1790 & 2100 & 4440 & 40 & 242 & 11700 \\
\hline 57 & 56 & ThyssenKrupp & Germany & 1770 & 1530 & 52831 & 3 & .. & 156860 \\
\hline 58 & 58 & Ukroboronprom & Ukraine & 1680 & 1440 & 1871 & 90 & 65 & 120000 \\
\hline 59 & 61 & Fincantieri & Italy & 1500 & 1300 & 5061 & 30 & 113 & 20390 \\
\hline 60 & 69 & Korea Aerospace Industries & South Korea & 1400 & 1030 & 1841 & 76 & 82 & 3140 \\
\hline$S$ & $S$ & Irkut (UAC) & Russia & 1320 & 1090 & 1818 & 73 & 14 & .. \\
\hline 61 & 63 & Diehl $^{i}$ & Germany & 1230 & 1200 & 3858 & 32 & . & 14520 \\
\hline 62 & 68 & Embraer & Brazil & 1210 & 1060 & 6325 & 19 & 361 & 19280 \\
\hline S & $S$ & Thales Systèmes Aéroportés & France & 1200 & 930 & 1200 & 100 & 105 & .. \\
\hline 63 & 59 & QinetiQ & UK & 1190 & 1410 & 1862 & 64 & .. & 6220 \\
\hline 64 & 92 & GenCorp & USA & 1120 & 830 & 1383 & 81 & 3 & 5390 \\
\hline 65 & 87 & Aselsan & Turkey & 1110 & 860 & 1140 & 97 & 125 & 5340 \\
\hline 66 & 88 & LIG Nexl & South Korea & 1100 & 850 & 1103 & 100 & 50 & 2920 \\
\hline $\mathrm{S}$ & $\mathrm{S}$ & UMPO (UEC) & Russia & 1100 & 760 & 1183 & 93 & 80 & .. \\
\hline 67 & 64 & Kongsberg Gruppen & Norway & 1080 & 1180 & 2778 & 39 & 208 & 7490 \\
\hline 68 & 55 & Mitsubishi Electric $f$ & Japan & 1070 & 1550 & 41540 & 3 & 1572 & 124310 \\
\hline
\end{tabular}




\begin{tabular}{|c|c|c|c|c|c|c|c|c|c|}
\hline \multicolumn{2}{|c|}{$\operatorname{Rank}^{b}$} & \multirow[b]{2}{*}{ Company $^{c}$} & \multirow[b]{2}{*}{ Country } & \multicolumn{2}{|c|}{$\begin{array}{l}\text { Arms sales } \\
\text { (US } \$ \mathrm{~m} .)\end{array}$} & \multirow{2}{*}{$\begin{array}{l}\text { Total } \\
\text { sales, } 2013 \\
\text { (US\$ m.) }\end{array}$} & \multirow{2}{*}{$\begin{array}{l}\text { Arms sales } \\
\text { as a \% of } \\
\text { total sales, } \\
2013\end{array}$} & \multirow{2}{*}{$\begin{array}{l}\text { Total } \\
\text { profit, } \\
2013 \\
\text { (US\$ m.) }\end{array}$} & \multirow{2}{*}{$\begin{array}{l}\text { Total } \\
\text { employment, } \\
2013\end{array}$} \\
\hline 2013 & 2012 & & & 2013 & 2012 & & & & \\
\hline 69 & 71 & Precision Castparts & USA & 1060 & 1010 & 9616 & 11 & 1784 & 29100 \\
\hline 70 & 70 & Triumph Group & USA & 1050 & 1030 & 3763 & 28 & 206 & 13830 \\
\hline 71 & 84 & Austal & Australia & 1030 & 880 & 1084 & 95 & 31 & . \\
\hline S & $S$ & Sevmash (USC) & Russia & 1030 & 1170 & 1369 & 75 & 6 & .. \\
\hline 72 & 75 & Krauss-Maffei Wegmann & Germany & 1010 & 980 & 1062 & 95 & .. & .. \\
\hline 73 & 83 & Patria Industries & Finland & 1000 & 890 & 1095 & 91 & 125 & 3610 \\
\hline 74 & 81 & Nexter & France & 990 & 910 & 1045 & 95 & 98 & 2780 \\
\hline 75 & 53 & Kawasaki Heavy Industries $f$ & Japan & 970 & 1850 & 14195 & 7 & 395 & 34620 \\
\hline 76 & 74 & Meggitt & $\mathrm{UK}$ & 960 & 990 & 2558 & 38 & 363 & 10720 \\
\hline 77 & 67 & Samsung Techwin & South Korea & 960 & 1080 & 2660 & 36 & 121 & 4930 \\
\hline 78 & 96 & RTI Systems & Russia & 950 & 800 & 1005 & 95 & .. & 10000 \\
\hline 79 & 82 & GKN & $\mathrm{UK}$ & 950 & 900 & 11150 & 8 & 636 & 49700 \\
\hline 80 & 66 & Chemring Group & $\mathrm{UK}$ & 920 & 1120 & 977 & 94 & .. & 3690 \\
\hline 81 & 72 & Jacobs Engineering Group ${ }^{h}$ & USA & 920 & 1000 & 11818 & 8 & 423 & 66500 \\
\hline S & S & $\begin{array}{l}\text { Austal USA (Austal } \\
\text { Australia) }\end{array}$ & USA & 900 & 750 & 902 & 100 & 60 & 4150 \\
\hline 82 & 76 & Bharat Electronics & India & 900 & 970 & 1054 & 85 & 159 & 9950 \\
\hline 83 & 65 & Navantia & Spain & 900 & 1130 & 943 & 95 & -80 & 5620 \\
\hline 84 & 77 & ASC & Australia & 890 & 950 & 886 & 100 & -4 & 2600 \\
\hline 85 & 107 & Hanwha & South Korea & 880 & 720 & 5236 & 17 & 110 & .. \\
\hline 86 & 62 & Uralvagonzavod $^{i}$ & Russia & 870 & 1220 & 2900 & 30 & .. & .. \\
\hline 87 & 91 & Hyundai WIA & South Korea & 870 & 830 & 5754 & 15 & 388 & .. \\
\hline 88 & 95 & Moog & USA & 860 & 820 & 2610 & 33 & 120 & 11150 \\
\hline 89 & 109 & Sozvezdie ${ }^{i}$ & Russia & 860 & 650 & 1140 & 75 & 25 & 17300 \\
\hline 90 & 86 & Cubic Corporation & USA & 840 & 870 & 1361 & 62 & 20 & 8200 \\
\hline 91 & 79 & RUAG & Switzerland & 830 & 930 & 1890 & 44 & 101 & 8240 \\
\hline 92 & 90 & AAR Corp. & USA & 830 & 840 & 2035 & 41 & 73 & 5800 \\
\hline 93 & 50 & $\mathrm{NEC}^{f}$ & Japan & 820 & 2050 & 31179 & 3 & 346 & 100910 \\
\hline 94 & 99 & $\mathrm{CNH}$ Industrial ${ }^{m}$ & $\begin{array}{l}\text { Trans- } \\
\text { European }\end{array}$ & 820 & 800 & 33800 & 2 & 1195 & 71192 \\
\hline S & S & $\begin{array}{l}\text { IVECO (CNH Industrial } \\
\text { Netherlands) }\end{array}$ & Italy & 820 & 800 & .. & .. & .. & 1180 \\
\hline 95 & 101 & $\mathrm{MIT}^{l}$ & USA & 810 & 780 & 884 & 92 & .. & 3700 \\
\hline 96 & 89 & CAE & Canada & 800 & 840 & 2053 & 39 & 185 & 8000 \\
\hline 97 & 104 & Alion Science \& Technology & USA & 800 & 750 & 849 & 94 & -37 & 2790 \\
\hline 98 & 94 & Ultra Electronics & USA & 800 & 820 & 1164 & 69 & 60 & 4570 \\
\hline 99 & 97 & The Aerospace Corp. ${ }^{i}$ & USA & 780 & 800 & 869 & 90 & . & 3450 \\
\hline 100 & 149 & Pilatus Aircraft & Switzerland & 770 & 280 & 1094 & 70 & 156 & 1750 \\
\hline
\end{tabular}

Source: SIPRI Arms Industry Database, retrieved 15 Dec. 2014.

${ }^{a}$ Although several Chinese arms-producing enterprises are large enough to rank among the SIPRI Top 100, it has not been possible to include them because of lack of comparable and sufficiently accurate data.

${ }^{b}$ Companies are ranked according to the value of their arms sales in 2013. An S denotes a subsidiary company. A dash (-) indicates that the company did not rank among the SIPRI Top 100 for 2012 Company names and structures are listed as they were on 31 Dec. 2013. Information about subsequent changes is provided in these notes. The 2012 ranks may differ from those published in SIPRI Yearbook 2014 and elsewhere owing to continual revision of data, most often because of changes reported by the company itself and sometimes because of improved estimations. Major revisions are explained in these notes.

${ }^{c}$ When the names of subsidiaries and operational companies owned by a holding or investment company differ, the name of the parent company is given in parentheses, along with its country if it differs.

${ }^{d}$ EADS was renamed Airbus Group in Jan. 2014. 
${ }^{e}$ Vertolety Rossii (Russian Helicopters) and United Engine Corporation are subsidiaries of OPK Oboronprom, but, since comparable financial data for Oboronprom for 2013 is not currently available, they are reported here as independent companies. On the consolidation of the Russian arms industry see Jackson, S. T., 'Arms production', SIPRI Yearbook 2011; Jackson, S. T., 'Arms production', SIPRI Yearbook 2010; and Perlo-Freeman, S. et al., 'The SIPRI Top 100 arms-producing companies, 2007', SIPRI Yearbook 2009, pp. 286-87.

${ }^{f}$ Arms sales figures for Japanese companies represent new military contracts rather than revenues.

$g$ Arms sales figures for Hewlett-Packard are based on data on US prime contract awards from USAspending.gov plus sales to the British Ministry of Defence from UK Defence Statistics. They may be underestimated because awards from classified contracts are not included in the US data.

${ }^{h}$ Arms sales figures for these companies are based on data on US prime contract awards from USAspending.gov. They may be underestimated because awards from classified contracts are not included in this data.

${ }^{i}$ Arms sales figures for these companies are estimates and are subject to a high degree of uncertainty.

${ }^{j}$ In September 2013, SAIC spun off its technical, engineering and IT services business. The spun-off segment retained the original company name: Science Applications International Corporation (SAIC). The parent company was renamed Leidos Holdings. Therefore, the figure for Leidos holdings in 2012 refers to the 2012 sales of the former SAIC.

${ }^{k}$ In September 2013, SAIC spun off its technical, engineering and IT services business. The spun-off business retained the original company name: Science Applications International Corporation (SAIC). The parent company was renamed Leidos Holdings. The new Science Applications company therefore does not have any rank or arms sales figure for 2012 as it is a new company.

${ }^{l}$ The Massachusetts Institute of Technology (MIT) runs federally funded research and development centers, including the Lincoln Laboratory, which conducts R\&D projects funded by the US Federal Government, including the Department of Defense (DOD). The arms sales of MIT refer to R\&D activities funded by the DOD.

${ }^{m}$ CNH Industrial was formed from the merger in 2013 of Fiat Industrial S.p.a. (which was separated from FIAT) and CNH Global NV. The arms sales of CNH Industrial for 2013 are those of IVECO, another Italian company. The figures given for 2012 also refer to the arms sales of IVECO, then a subsidiary of FIAT. While headquartered in the Netherlands, CNH Industrial is listed on the Italian and US stock exchanges and has its primary operational activities in Italy, including IVECO. It is therefore treated as an Italian company in the Top 100 for statistical purposes.

in 2012 (35 per cent), but it remains a significant increase. A large part of the 2013 growth is attributable to sales increases for Tactical Missiles Corporation (a 118 per cent increase from 2012), Almaz-Antey (up 34 per cent) and United Aircraft Corporation (up 20 per cent). The Russian company entering the list in 2013 is Sozvezdie, which ranked 109 in 2012.

The 2013 increases in arms sales by Russian companies are largely due to the current State Armaments Plan's ongoing project to strengthen indigenous arms procurement.

\section{The United States}

The small decline in arms sales for US companies that started in 2011 continued in 2013 with a 4.5 per cent decrease in the total estimated arms sales of the 38 Top 100 US-ranked companies compared with 2012. This figure indicates that domestic budgetary pressures have, so far, not dealt a major blow to the bottom lines of the largest US arms producers.

As in 2012, the most severely affected companies were those that were highly dependent on sales of services and equipment for the overseas operations of the US armed forces. Notably, the service provider KBR is no longer listed on the Top 100, despite being ranked 14 in 2009. Owing to the decline in domestic demand and continued uncertainty regarding future US military procurement spending, several US Top 100 companies (mostly those involved in providing services) have divested from some military production activities. This explains the significant (50 per cent) fall in the arms sales of Science Application International Corporation (SAIC), a technical and 
Box 1. Chinese arms-producing companies

Chinese companies are not covered by the SIPRI Top 100 due to the lack of data on which to make a reasonable estimate of arms sales for most companies. Nonetheless, some information is available on the 10 major state-owned conglomerates under which most of the Chinese arms industry is organized. According to information from their financial reports, these 10 companies had total sales of around 1608 billion yuan (\$268 billion) in 2012. ${ }^{a}$ However, these companies each comprise hundreds of individual enterprises and produce a wide range of civil and military products. The latter represent a minority of the total sales-estimated to be 24 per cent in 2006 and 28 per cent in 2007-and the share is not generally known on a company-by-company level.

China's military spending more than quadrupled in real terms between 2000 and 2012, and the country has engaged in major efforts to develop its domestic industry. As a result, since the late 2000s China has been decreasing its arms imports in favour of domestic procurement. In addition, China's arms exports have grown substantially in the past decade, to the extent that the country is now the fifth largest arms exporter, just after France.

Based on the overall industry picture and on limited information on individual companies, at least 9 of these 10 companies would almost certainly be in the Top 100 if figures for arms sales were available. Of these, 4 to 6 would probably be in the top 20 , and one-the aviation company AVIC-may be in the top 10.

a Cheung, T. (ed.), The Chinese Defense Economy Takes Off: Sector-by-Sector Assessments and the Role of Military End Users (University of California Institute on Global Conflict and Cooperation: La Jolla, CA, 2013).

IT services company, whose military activities continue under a new name, Leidos, which is ranked 22 in the 2013 Top 100.

\section{West European producers}

The sales picture for West European arms producers for 2013 was mixed, as some countries' companies showed growth while other declined. In the United Kingdom, the second largest arms-selling country in the world in 2013, half of the 10 British companies ranked in the 2013 Top 100 had minor drops in their arms sales. The remaining five British companies had an average arms sales increase of 7 per cent for 2013.

In Western Europe, two of the most important increases in total arms sales from 2012 in real terms were those of French companies: the naval shipbuilder DCNS (23 per cent) and the combat aircraft manufacturer Dassault (21 per cent). Spain's only ranking company, the naval shipbuilder Navantia, continued its descent in the Top 100 ranking from 65 to 83, reflecting the country's persistent economic difficulties as well as export fluctuations. The same was true of Italy's Finmeccanica, whose 10 per cent drop in arms sales highlights the close correlation between national economic woes and arms revenues.

These contrasting trends for the region indicate diverse national situations with regard to government procurement priorities as well as different rates of success for major West European arms producers in export markets. They also underline the fragmented character of the European arms industry, which is still strongly associated with national markets. In this regard, export successes have become increasingly important to these producers because of the national economic environment.

\section{Emerging producers}

Establishing the category 'emerging producers' in the Top 100 seeks to address the growing importance and ambition of arms-producing companies 
SIPRI is an independent international institute dedicated to research into conflict, armaments, arms control and disarmament. Established in 1966, SIPRI provides data, analysis and recommendations, based on open sources, to policymakers, researchers, media and the interested public.

\section{GOVERNING BOARD}

Sven-Olof Petersson, Chairman (Sweden)

Dr Dewi Fortuna Anwar

(Indonesia)

Dr Vladimir Baranovsky (Russia)

Ambassador Lakhdar Brahimi (Algeria)

Jayantha Dhanapala

(Sri Lanka)

Ambassador Wolfgang Ischinger (Germany)

Professor Mary Kaldor (United Kingdom)

The Director

\section{DIRECTOR}

Dr Ian Anthony (United Kingdom)

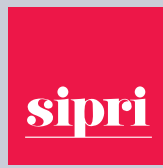

STOCKHOLM INTERNATIONAL PEACE RESEARCH INSTITUTE Signalistgatan 9 SE-169 70 Solna, Sweden Telephone: +4686559700 Fax: +4686559733

Email: sipri@sipri.org Internet: www.sipri.org that are based in countries in the Global South. Collectively, Brazil, India, South Korea, Singapore and Turkey represent a small part of total Top 100 arms sales, but increases in arms sales-as well as the significant goals set by these countries' governments both in terms of indigenous production of armaments and export strategies-call for better tracking of their trajectory in the ranks of top arms producers.

The growing South Korean arms industry is primarily based on significant domestic demand, including major involvement in component production for the US arms industry as part of offset programmes for imported arms. The sales of Korea Aerospace industries (KAI) grew 31 per cent from 2012 to 2013. However, the South Korean arms industry is also looking to secure a position within the arms export market.

Of emerging producers ranked in the 2013 Top 100, India has the second highest number of companies (three), showing equivalent sales to those of the five ranking South Korean companies. Even though successive Indian governments have stated their intention to develop a comprehensive, technologically advanced indigenous arms industry, India's capacity to reach that goal remains questionable. Sales are mainly based on bulk licence production of foreign-designed weapons, while the development of indigenous systems has been plagued with problems for decades. The Indian industry's role in the arms export market is also negligible. Nevertheless, success in the export market remains a central goal of the current government, and significant national resources are dedicated to attaining it.

Brazil's aviation company Embraer and Turkey's electronics company Aselsan have both significantly increased their positions in the Top 100 since first appearing on the list in 2011 and 2010, respectively. Their introductions corresponded to increased arms sales and to the exit of companies from the Global North from the Top 100. Both companies have remained in the SIPRI Top 100 since 2010.

\section{ABOUT THE AUTHORS}

Dr Aude Fleurant (France) is the Director of the SIPRI Arms and Military Expenditure Programme.

Dr Sam Perlo-Freeman (United Kingdom) is a Senior Researcher and the Head of the SIPRI Military Expenditure Project.

Arms industry data was supplied by the SIPRI Arms Industry Network: Lucie BéraudSudreau (Université Paris 2 Panthéon-Assas), Gülay Günlük-Şenesen (Istanbul University), Jang Won Joon (Korea Institute for Industrial Economics and Trade, Seoul), Shinichi Kohno (Mitsubishi Research Institute, Tokyo), Pere Ortega (Centre d'Estudis per la Pau J. M. Delàs, Barcelona) and Alessandro Ungaro (Istituto Affari Internazionali, Rome). 